\title{
ArcheoSciences
}

Revue d'archéométrie

33 (suppl.) | 2009

Mémoire du sol, espace des hommes

\section{Archaeological maps: methods and techniques for territorial analysis}

Leonor Rocha and Gertrudes Branco

\section{(2) OpenEdition}

1 Journals

\section{Electronic version}

URL: https://journals.openedition.org/archeosciences/1461

DOI: 10.4000/archeosciences. 1461

ISBN: 978-2-7535-1599-4

ISSN: 2104-3728

Publisher

Presses universitaires de Rennes

\section{Printed version}

Date of publication: 30 October 2009

Number of pages: 141-142

ISBN: 978-2-7535-0943-6

ISSN: $1960-1360$

\section{Electronic reference}

Leonor Rocha and Gertrudes Branco, "Archaeological maps: methods and techniques for territorial analysis", ArcheoSciences [Online], 33 (suppl.) | 2009, Online since 30 October 2011, connection on 21 September 2021. URL: http://journals.openedition.org/archeosciences/1461 ; DOI: https://doi.org/ 10.4000/archeosciences. 1461 


\title{
Archaeological maps: methods and techniques for territorial analysis
}

\author{
Leonor Rocha* and Gertrudes Branco**
}

Key words: Prospection, Methodologies, Archaeological Maps, Portugal, Territory.

Archaeological maps are, by definition, a tool for the management of the cultural heritage, planning and urban development, and are drawn up on the basis of existing studies and recent fieldwork, covering all the latest data.

In Portugal, the idea of creating a national archaeological map was developed, for the first time, in the 1970s. However, several attempts to organize such amount of information have been offset by two major problems: the difficulty of mapping such a large area, and the lack of available funding to carry it out. As a result, the only archaeological maps that have been made are those covering local districts, or counties, funded by local authorities that have opted to invest in this area because of the number and importance of heritage sites known in its territory; only around fifty local councils have such maps.

In the late $20^{\text {th }}$ century, the Instituto Português de Arqueologia (Portuguese Archaeological Institute), the institution responsible for supervising archaeological works in Portugal, under the Culture Ministry, set up a national database, Endovelico. Despite progress on the database having completely ground to a halt, it covers around 26,000 archaeological sites and constitutes an important source of archaeological information in Portugal.

While the main purpose of archaeological field survey is to gather knowledge about a territory, verifying the existence or otherwise of archaeological sites within a given space (Ferreruela Gonzalvo, 2001-2202), the recognition of its importance is due firstly to the emphasis on territorial and spatial archaeology brought about by the "New Archaeology" and secondly to the increased importance of archaeological surveys carried out as part of large-scale public and private development projects with the need for areas to be assessed for the purpose of protection.

The methodologies used in archaeological field surveys vary from the systematic to the selective, depending on the objectives involved. Because field survey is a non-destructive method of research it can be less rigid (than, for instance, excavation work) and applied in a flexible strategy, during its execution, as more specific information about the territory is being gathered; field survey work is usually informed by the analysis of existing studies, toponyms, maps, aerial photographs and geological data.

Nowadays, archaeologic surveyors face an increasing number of difficulties, as examples: agricultural machinery can disturb or destroy evidence of ancient landscapes; the strong impact on the landscape, and unexcavated heritage, caused by the building of infrastructures (for example, dams, roads and buildings); on the other side, traditional information about the territory is continually being lost as the older generation of rural people, with strong ties to the land and cultural traditions, and an excellent knowledge of the local area, is passing away, implying the loss of a very important source of oral information.

The experience of a team of field surveyors is of utmost importance; the lack of such experience, coupled with poor knowledge of the local area, can result in insufficient results.

*CIDEHUS/ Universidade de Evora. (Improcha@gmail.com)

** Universidade de Évora. (gertrudes.branco@gmail.com) 
In fact, from the analysis of the archaeological maps available in Portugal, most of them made in the $20^{\text {th }}$ century (see map and chart), it is evident that the obtained results were determined by the experience of archaeologists involved in field work.

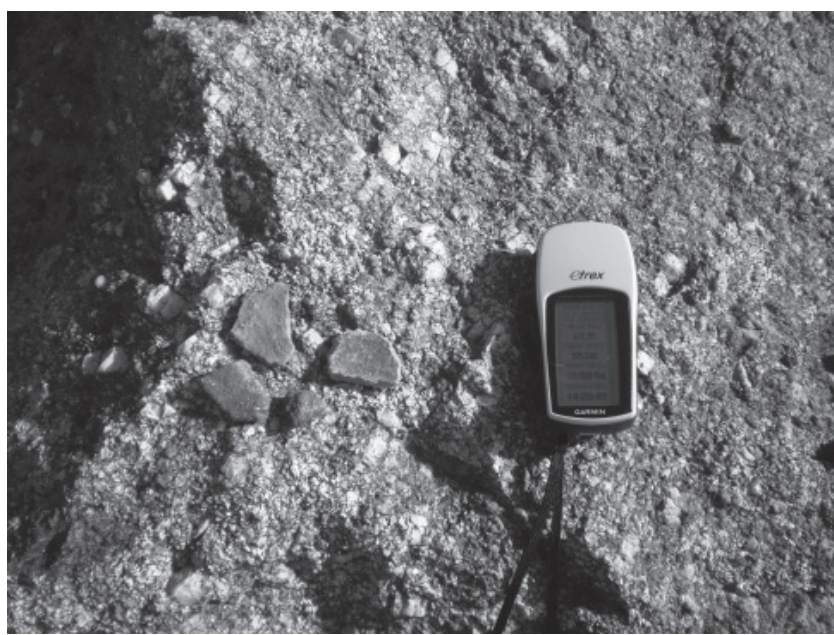

Figure 1: Evolution in Archaeological Maps (Portugal).

At the moment we are able to say that archaeological maps in Portugal, as a generalized procedure of gathering information about archaeological heritage and produce inventories to be used in urban and land planning, is not yet standard practice and still needs refinement regarding methods and theories involved. This work aims to be a contribution to this theme.

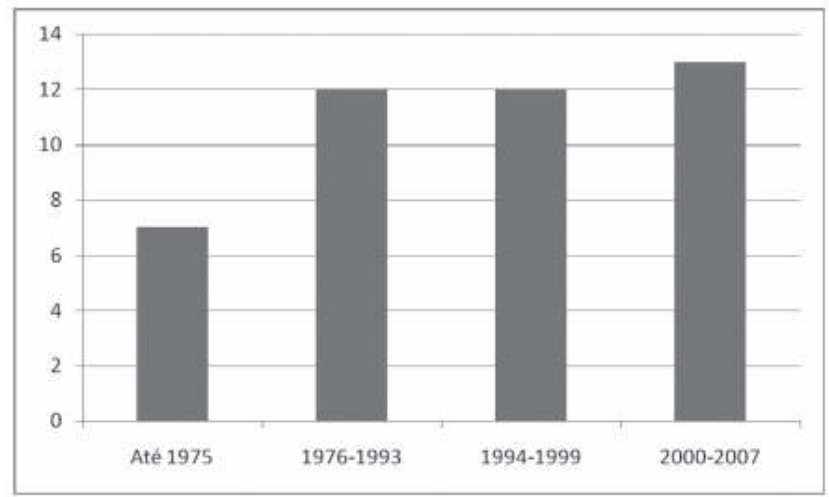

Figure 2: Prospecting register.

\section{References}

Calado, M. 1993. Carta Arqueológica do Alandroal. Alandroal: Câmara Municipal de Alandroal.

Calado, M. and Mataloto, R., 2001. Carta Arqueológica do Redondo. Redondo: Câmara Municipal de Redondo.

Carneiro, A., 2005. Carta arqueológica do concelho de Fronteira. Lisboa: Colibri.

Ferreruela Gonzalvo, A, Mínguez Morales, J. A and Picazo Millán, J. V., 2003. Prospecciones arqueológicas realizadas en los términos municipales de el Burgo de Ebro, Fuentes de Ebro y Zaragoza. Años de 1995-2000: memoria de las actuaciones. SALDUIE, Estúdios de prehistoria y arqueologia. 2: 389-408.

Marques, T. and Araújo, A. C., 1995. Carta arqueológica de Portugal: concelhos de Faro, Olhão, Tavira, Vila Real de Santo António, Castro Marim e Alcoutim. Lisboa: IPPAR.

Oliveira, J., Pereira, S. and Parreira, J., 2007. Nova Carta Arqueológica do Concelho de Marvão. Revista Ibn-Maruan, 14.

Paço, A., 1953. Carta Arqueológica do concelho de Marvão. Lisboa: Imprensa Nacional.

Paço, A. and Elísero, P., 1964. Subsidios para uma carta arqueológica do concelho de Vila do Conde. Guimarães: [s.n.]

Ramos, C. and Araújo, A. C. B., 1992. Carta Arqueológica de Portugal: concelhos de Portimão, Lagoa, Silves, Albufeira, Loulé e São Brás de Alportel. Lisboa: IPPAA.

Rodrigues, M. C., 1975. Carta Arqueológica do concelho de Castelo de Vide. Lisboa: [s. n.].

Serrấ, E. C., 1973. Carta arqueológica do concelho de Sesimbra. Setúbal: Junta Distrital de Setúbal.

Silva, E. J., 1996. Carta arqueológica do Concelho de Castelo de Paiva. Porto: Universidade Portucalense.

Souto, E. A., 1958. Subsídios para uma carta arqueológica do distrito de Aveiro no período da romanização. Arquivo Distrito Aveiro, V. 24 